\title{
Migratory connectivity and temporal segregation of dunlin (Calidris alpina) in Portugal: evidence from morphology, ringing recoveries and $m$ tDNA
}

Received: 11 February 2005/ Revised: 15 July 2005/ Accepted: 1 August 2005/ Published online: 25 January 2006 (C) Dt. Ornithologen-Gesellschaft e.V. 2006

\begin{abstract}
Migratory connectivity plays an important role in conservation of long-distance migrant birds. Here, we study migratory links of dunlin (Calidris alpina), focusing on a stopover and wintering region (Portugal) where it is known that migration routes of dunlin from a broad geographic range (three subspecies) converge, and populations occur simultaneously or separated in time. We combine three methods (ringing recoveries, morphometrics and molecular genetics) to assess breeding origins and extent of temporal segregation of dunlin assemblages. Ringing recoveries show temporal separation of dunlin from different migration routes. Birds found in Portugal during August and September, migrating via Britain, reveal links to breeding areas in Iceland and Greenland. In October, a clear shift to more eastern migration routes occurs, with most Portuguese winter records from stopover sites along migration routes of populations from northern Scandinavia and Russia. Mitochondrial DNA (mtDNA) of Portuguese dunlin was compared with breeding populations. Spring and autumn migrants in Portugal corresponded to C. $a$. schinzii and C. a. arctica populations, while the Portuguese winter population clearly differs by including
\end{abstract}

Communicated by F. Bairlein

R. J. Lopes ( $($ )

Research Center in Biodiversity and Genetic Resources, University of Porto, Campus Agrário de Vairão,

Rua Padre Armando Quintas, Crasto,

4485-661 Vairao, Portugal

E-mail: ricardolopes@mail.icav.up.pt

Tel.: 351-252-660416

Fax: 351-252-661780

J. C. Marques · R. J. Lopes

Department of Zoology, Institute of Marine Research,

University of Coimbra, 3004-517 Coimbra, Portugal

L. Wennerberg

National Centre for Biosystematics, National History Museum, University of Oslo, P.O. Box 1172,

Blindern, 0318 Oslo, Norway
mtDNA haplotypes of C. a. alpina. For genetically sexed individuals, we found significant differences in morphology (bill and tarsus length) supporting the temporal separation of populations/subspecies revealed by recoveries and mtDNA. Our results give evidence for migratory connectivity of dunlin populations between geographic areas previously not considered connected. They confirm the existence of clear differences in breeding origin between birds in Portugal at different times of year. These results are important in the consideration of future long-term conservation plans.

Keywords Animal conservation - Bird migration . Migratory connectivity · Mitochondrial DNA . Population genetics

\section{Introduction}

Migratory connectivity plays a major role in conservation of long-distance bird migrants, such as waders (Webster et al. 2002). The long-term survival of migratory species depends on the protection of suitable habitats along the migratory routes, and protection of breeding as well as wintering habitats. However, different breeding populations may use different stopover and wintering sites. Therefore, a more detailed discrimination at the population level is crucial for the understanding of how local habitat changes will affect the species globally and vice versa. For instance, global climate change may affect conditions on breeding habitats all over the world, as well as having locally important effects on habitats used during the non-breeding season (Lindström and Agrell 1999; Galbraith et al. 2002).

The dunlin (Calidris alpina) is a long-distance migrant with a circumpolar breeding distribution. Nine subspecies are recognized by del Hoyo et al. (1996), defined mainly by morphological characters (e.g. size and plumage coloration). Three of these subspecies (C. a. arctica, C. a. schinzii and C. a. alpina) occur on the East Atlantic 
flyway (Greenwood 1986). This flyway includes stopover sites along the western coasts of Europe and Africa, linking breeding grounds from Greenland to Siberia with wintering areas in Europe and Africa (Smit and Piersma 1989). The occurrence of recently observed population declines, in particular for $C$. a. schinzii populations in NW Europe (Wetlands International 2002), and potential mixing of populations make discrimination of their different migration routes and wintering grounds essential for conservation.

To estimate differences and origin of dunlin flocks found on stopover and wintering sites, morphological characters (e.g., bill, tarsus, wing, plumage) have often been used (Pienkowski and Dick 1975; Wymenga et al. 1990). However, substantial overlap in morphology occurs between subspecies (Greenwood 1986; Engelmoer and Roselaar 1998). Due to sexual size dimorphism, reliable analysis of morphological data also requires accurately sexed birds. However, migrating and wintering dunlin are difficult to sex reliably in the field (Prater et al. 1977) and, therefore, most of these studies have used statistical methods to deal with this problem. The accuracy of these methods relies on a priori assumptions concerning sex ratio and subspecies. This problem can now be overcomed more accurately by using genetic sexing methods (e.g., Wennerberg et al. 2001).

Recoveries of ringed birds have been valuable for revealing links between stopover and wintering sites for dunlin (e.g., Pienkowski and Evans 1984), but few ringing recoveries link breeding areas directly to wintering sites (Greenwood 1984; Gromadzka 1989; Gromadzka and Ryabitsev 1998). This is mainly due to biased ringing and recovery effort, which is higher in Europe than in Arctic and African regions.

These different methodologies have already provided data that broadly characterize the migration system of dunlin along the East Atlantic flyway. It has been shown that winter segregation occurs between subspecies. The populations of C. a. alpina winter in the northern range of the wintering grounds, from northern Europe to Morocco. The C. a. schinzii populations winter further south in Europe and in Africa. The C. a. artica populations also winter in NW Africa (Greenwood 1984; del Hoyo et al. 1996; Snow and Perrins 1998). However, few data areavailable for quantification of their relative importance in large regions where population overlap may occur.

Molecular methods have also been applied in studies of migrating birds (Kimura et al. 2002; Webster et al. 2002). In dunlin, DNA sequencing of the mitochondrial DNA (mtDNA) control region revealed five major phylogenetic lineages with different geographic distributions on a global scale on dunlin (Wenink et al. 1993; Wennerberg 2001). These markers can be applied to tracing the breeding origin of dunlin sampled outside the breeding areas throughout the annual cycle (Wenink and Baker 1996; Wennerberg 2001). On the East Atlantic flyway, two mtDNA types occur: European (Eur) and Siberian (Sib) haplotypes (lineages). The frequency of
European haplotype decreases with longitude while the Siberian haplotype increases (Wennerberg 2001), which enables us to compare the haplotype composition in flocks of migrant dunlin to haplotype frequencies in breeding populations along a longitude gradient, and thereby estimate the probability of matching between breeding populations and non-breeding birds.

Portuguese coastal habitats are used by dunlin populations as stopover and wintering sites in the East Atlantic flyway. More than 62,000 dunlin stay during winter and many birds use Portuguese stopover sites during migration to southern wintering grounds, e.g. in West Africa (Delany et al. 1999). However, very little information is available to quantify the relative importance of the different populations in Portugal (see Batty 1993). The aim of this study was to analyse and quantify the composition of non-breeding dunlins in Portugal and estimate their breeding origin. In order to compare with the known information from previous analysis, we used an integrative approach where these different methods were combined: morphometrics, ringing recoveries and molecular genetics (sexing and mtDNA).

\section{Methods}

\section{Ringing recoveries}

A total of 270 records were compiled from the Portuguese National Ringing Centre database and from other older published records (Freire 1969; Ferreira 1980). They included 73 foreign recoveries of dunlin ringed in Portugal and 197 foreign ringed birds recovered in Portugal. These recoveries ranged from 1954 to 1999. Maps showing the geographic distribution of the recoveries were drawn in Arcgis 8.3 (ESRI, USA) using Mollweide's equal area projection.

\section{Population sampling}

Dunlin were sampled in the Mondego and Tagus estuaries (Fig. 1), on the west coast of Portugal, during spring migration (2-22 May), autumn migration (7 August-2 October) and winter (20 December-18 January) in 1999-2001 (Table 1). The birds were captured in mist nets during high tide, while foraging or roosting on saltpans at night. They were aged in two classes (juvenile and adult) according to Prater et al. (1977). Two morphological characters were used in the analyses: bill length (measured from the feather base to the tip of bill) and tarsus length (Bent method; see details in Svensson 1992). They were measured to the nearest $0.1 \mathrm{~mm}$ using calipers and all measurements were taken by Lopes. Blood samples of 20-50 $\mu$ were taken from all birds by venipuncture of the brachial vein. The blood was stored in SET buffer $(0.15 \mathrm{M} \mathrm{NaCl}$, $0.05 \mathrm{M}$ TRIS, $0.001 \mathrm{M}$ EDTA, $\mathrm{pH}=8.0$ ) and frozen to $20^{\circ} \mathrm{C}$, or stored in $95 \%$ alcohol at $7^{\circ} \mathrm{C}$. 


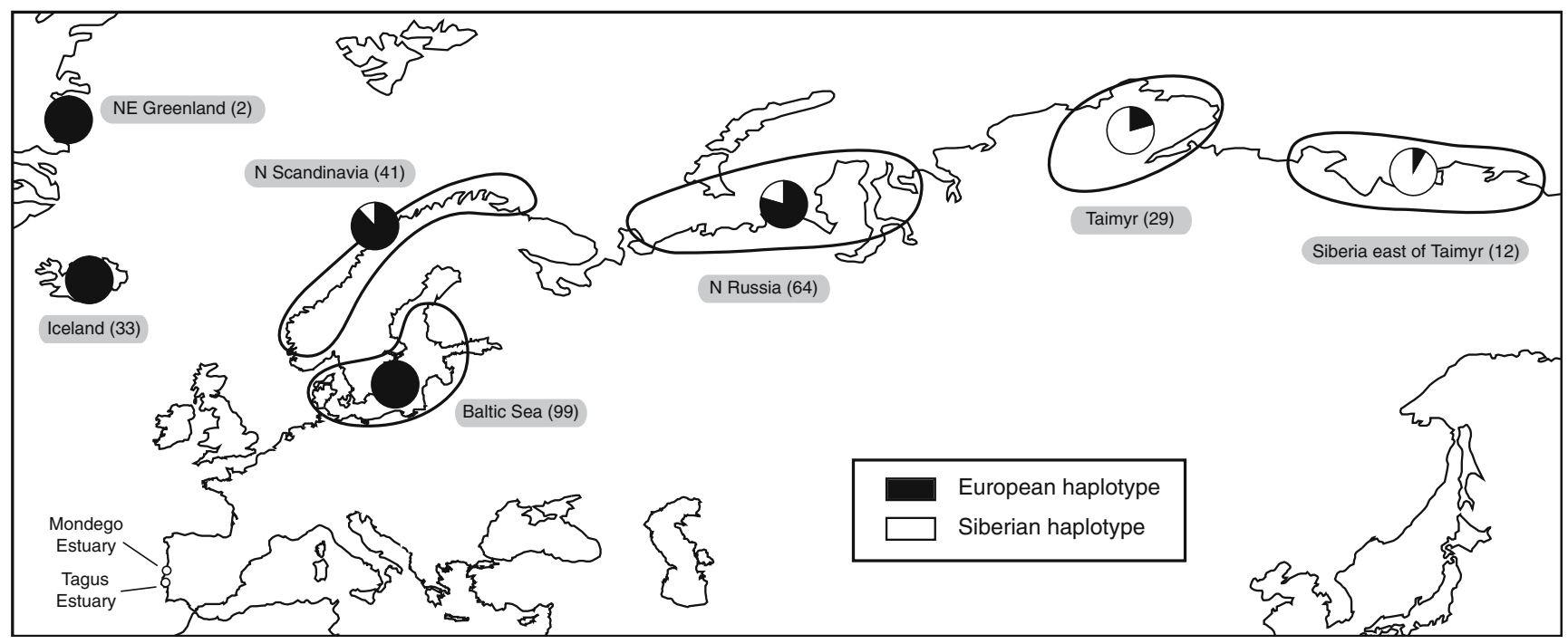

Fig. 1 The mitochondrial DNA haplotype frequencies of dunlin (Calidris alpina) from the different breeding regions. Each pie shows the proportion of the European (black) and Siberian (white) haplotypes at each breeding region. Sample sizes are shown next to each pie. (Pies represent pooled data assembled from different

\section{Mitochondrial DNA}

DNA was extracted by phenol/chloroform extraction according to standard procedures (Sambrook et al. 1989; Smith et al. 1996). A segment (295 bp) of the mtDNA control region was amplified by polymerase chain reaction (PCR), using the primers L 98 and $\mathrm{H} 401$ (Wenink et al. 1993). The PCR contained 1.0 $\mu$ DNA breeding sites: adapted from Wenink et al. 1993; Wenink and Baker 1996; Wennerberg et al. 1999; Wennerberg 2001; L. Wennerberg, unpublished data). Also shown are the locations of the Mondego and Tagus estuaries

$(10 \mathrm{ng} / \mu \mathrm{l}), 2.5 \mu \mathrm{l}$ of each primer $(10 \mu \mathrm{M}), 2.5 \mu \mathrm{l}$ $10 \times$ PCR buffer (Boehringer Manheim, Germany), $5 \mu \mathrm{l}$ dNTP $(1.25 \mathrm{mM}$ of each nucleotide), $2 \mu \mathrm{l} \mathrm{MgCl}$

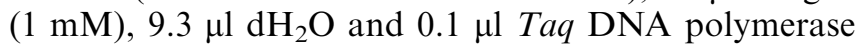
(1 unit). The PCR included 2 min at $94^{\circ} \mathrm{C}, 35$ cycles of (30 s at $94^{\circ} \mathrm{C}, 30 \mathrm{~s}$ at $54^{\circ} \mathrm{C}$ and $30 \mathrm{~s}$ at $72^{\circ} \mathrm{C}$ ), followed by 25 cycles of $\left(30 \mathrm{~s}\right.$ at $94^{\circ} \mathrm{C}, 30 \mathrm{~s}$ at $48^{\circ} \mathrm{C}$ and $1 \mathrm{~min}$ at $72^{\circ} \mathrm{C}$ ), and finally $72^{\circ} \mathrm{C}$ for $10 \mathrm{~min}$. PCR products were

Table 1 Sampling dates, age, sex composition and mitochondrial DNA haplotypes of Portuguese dunlin (Calidris alpina). Spring and autumn migration samples were collected from the Mondego estuary, winter samples from the Tagus estuary

\begin{tabular}{|c|c|c|c|c|c|c|c|c|c|}
\hline & \multirow[t]{3}{*}{$n$} & \multicolumn{4}{|c|}{ Juvenile } & \multicolumn{4}{|c|}{ Adult } \\
\hline & & \multicolumn{2}{|c|}{ Male } & \multicolumn{2}{|c|}{ Female } & \multicolumn{2}{|c|}{ Male } & \multicolumn{2}{|c|}{ Female } \\
\hline & & Eur & Sib & Eur & Sib & Eur & Sib & Eur & $\mathrm{Sib}$ \\
\hline \\
\hline 9 May 1999 & 1 & - & - & - & - & -14 & - & 1 & - \\
\hline 17-18 Мay 2001 & 20 & 2 & - & 4 & - & 5 & - & 9 & - \\
\hline 22 May 1999 & 4 & 1 & - & 1 & - & - & - & 2 & - \\
\hline Total & 48 & 7 & - & 7 & - & 19 & - & 15 & - \\
\hline \multicolumn{10}{|l|}{ Autumn migration } \\
\hline 7 August 1999 & 2 & - & - & - & - & 1 & - & 1 & - \\
\hline 19-21 August 1999 & 11 & 1 & - & 4 & - & 3 & - & 3 & - \\
\hline 3-4 September 1999 & 17 & 6 & - & 10 & - & - & - & 1 & - \\
\hline 19 September 1999 & 5 & 3 & - & 2 & - & - & - & - & - \\
\hline 2 October 1999 & 20 & 10 & - & 10 & - & - & - & - & - \\
\hline Total & 55 & 20 & - & 26 & - & 4 & - & 5 & - \\
\hline \multicolumn{10}{|l|}{ Winter } \\
\hline 20 December 2000 & 18 & - & - & 5 & - & 5 & 1 & 5 & 2 \\
\hline 2 January 2001 & 32 & - & - & 2 & - & 8 & 4 & 14 & 4 \\
\hline 18 January 2001 & 30 & 2 & - & 3 & - & 10 & 4 & 9 & 2 \\
\hline Total & 80 & 2 & - & 10 & - & 23 & 9 & 28 & 8 \\
\hline Total & 183 & 29 & - & 43 & - & 46 & 9 & 48 & 8 \\
\hline
\end{tabular}


cut using the restriction enzyme $A l u \mathrm{I}$ for $3 \mathrm{~h}$. $A l u \mathrm{I}$ was chosen because it specifically cuts the mtDNA at positions that differs between two mtDNA types: the European and Siberian haplotypes (Wenink and Baker 1996; Wennerberg 2001). DNA fragments were separated by electrophoresis in 2\% agarose gels containing ethidium bromide and scanned using a FluoroImager. The length of each band was compared with reference bands of all haplotypes, as well as with a size marker (1-kb DNA ladder; Life Technologies).

In order to compare these non-breeding groups of birds with breeding populations, a revised compilation of mtDNA data of 280 breeding birds from 22 breeding populations (Fig. 1) were assembled from Wenink et al. (1993), Wenink and Baker (1996), Wennerberg et al. (1999), and Wennerberg (2001). Additional unpublished data was also included (L. Wennerberg, unpublished data).

\section{Sex determination}

The sex of dunlin of unknown breeding population origin is difficult to determine in the field with biometrics and plumage characteristics. Therefore, we used a molecular genetic sexing method. DNA from the sex chromosomes ( $\mathrm{Z}$ and $\mathrm{W}$ ) was amplified by PCR, using the primers $\mathrm{P} 2$ and P8 (Griffiths et al. 1998). The reaction contained $1.0 \mu \mathrm{l}$ DNA $(10 \mathrm{ng} / \mu \mathrm{l}), 1.0 \mu \mathrm{l}$ primer (15 pmol), $1.0 \mu \mathrm{l} 10 \times$ PCR buffer (Boehringer Manheim, Germany), $1.0 \mu \mathrm{dNTP}$ (1.25 mM of each nucleotide), $0.7 \mu \mathrm{MgCl}(1 \mathrm{mM}), 5.2 \mu \mathrm{dH} 2 \mathrm{O}$ and $0.1 \mu \mathrm{l} \mathrm{Taq}$ DNA polymerase (1 unit). The PCR included $2 \mathrm{~min}$ at $94^{\circ} \mathrm{C}$, a touchdown procedure with 10 cycles of $\left(30 \mathrm{~s}\right.$ at $94^{\circ} \mathrm{C}$, $30 \mathrm{~s}$ at $58^{\circ} \mathrm{C}-1^{\circ} \mathrm{C} /$ cycle and $1 \mathrm{~min}$ at $72^{\circ} \mathrm{C}$ ), followed by
25 cycles of $\left(30 \mathrm{~s}\right.$ at $94^{\circ} \mathrm{C}, 30 \mathrm{~s}$ at $48^{\circ} \mathrm{C}$ and $1 \mathrm{~min}$ at $72^{\circ} \mathrm{C}$ ), and finally $72^{\circ} \mathrm{C}$ for $10 \mathrm{~min}$. The PCR products were separated by electrophoresis in $2 \%$ agarose gels containing ethidium bromide, using 1-kb DNA ladder as reference, and scanning gel using a FluoroImager.

\section{Statistics}

Univariate comparison of male and female bill and tarsus length were compared between seasons (one-way ANOVA), followed by post hoc tests (Tukey test; Zar 1999). Differences in haplotype frequencies between sampling periods were tested using Fisher exact test (Zar 1999). The 95\% confidence intervals were estimated (Zar 1999). All univariate statistics were performed with SPSS 11.0 (SPSS, Chicago, Ill.), except for proportions confidence intervals and power calculations that were performed with Minitab 12 (Minitab, State College, Pa.).

\section{Results}

\section{Ringing recoveries}

Clear differences in migration routes were shown by analysis of ringing recoveries of Portuguese dunlin from different parts of the year. The recoveries also indicate seasonal variation in the occurrence of different dunlin populations/subspecies in Portugal (Figs. 2, 3).

During autumn migration, a gradual shift to more eastern migration routes occurred from August to October. Most birds recorded in Portugal in August showed links to Britain. Birds from Iceland and

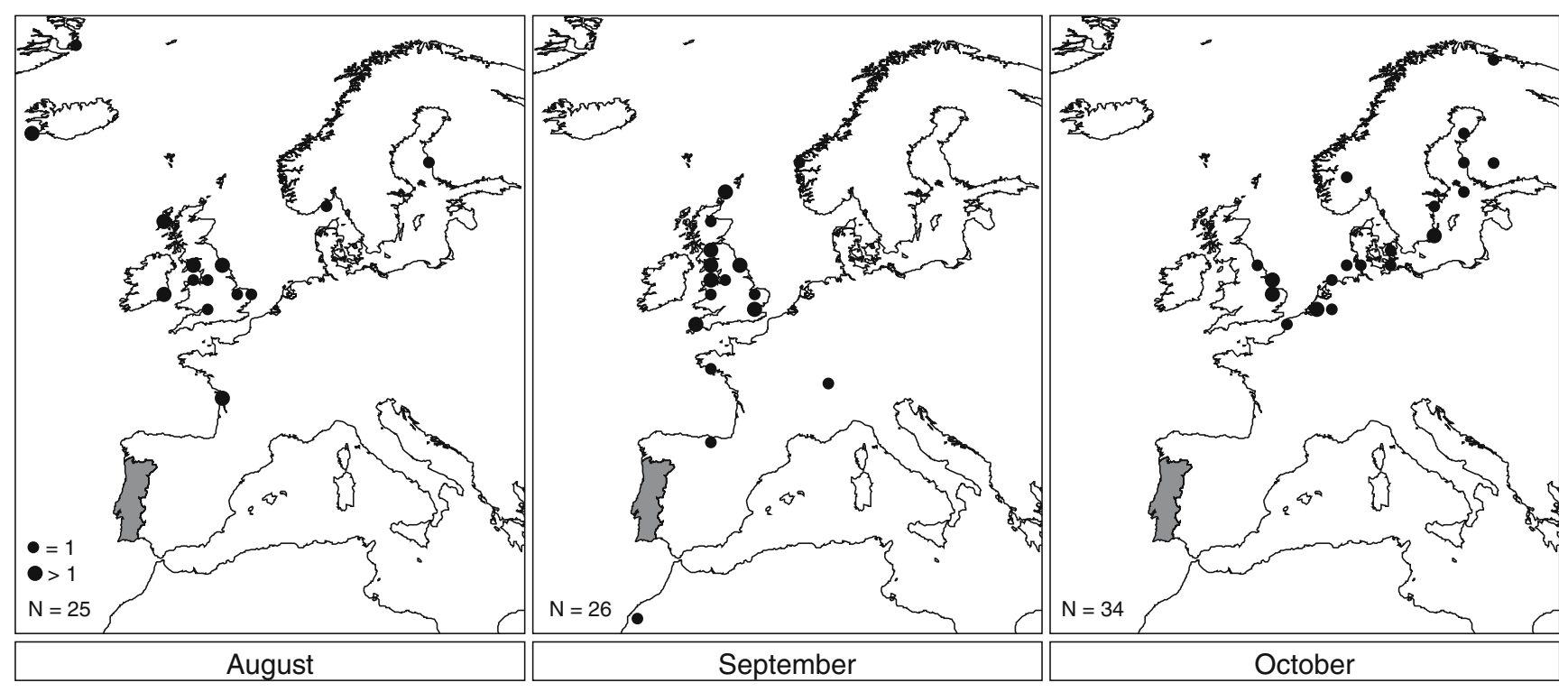

Fig. 2 Ringing locations of dunlin recovered in Portugal and recovery locations of dunlin ringed in Portugal during autumn migration (August, September and October). Each dot represents

all recoveries within a grid of $50 \mathrm{~km}$. Small dots indicate single samples and large dots more than one individual 

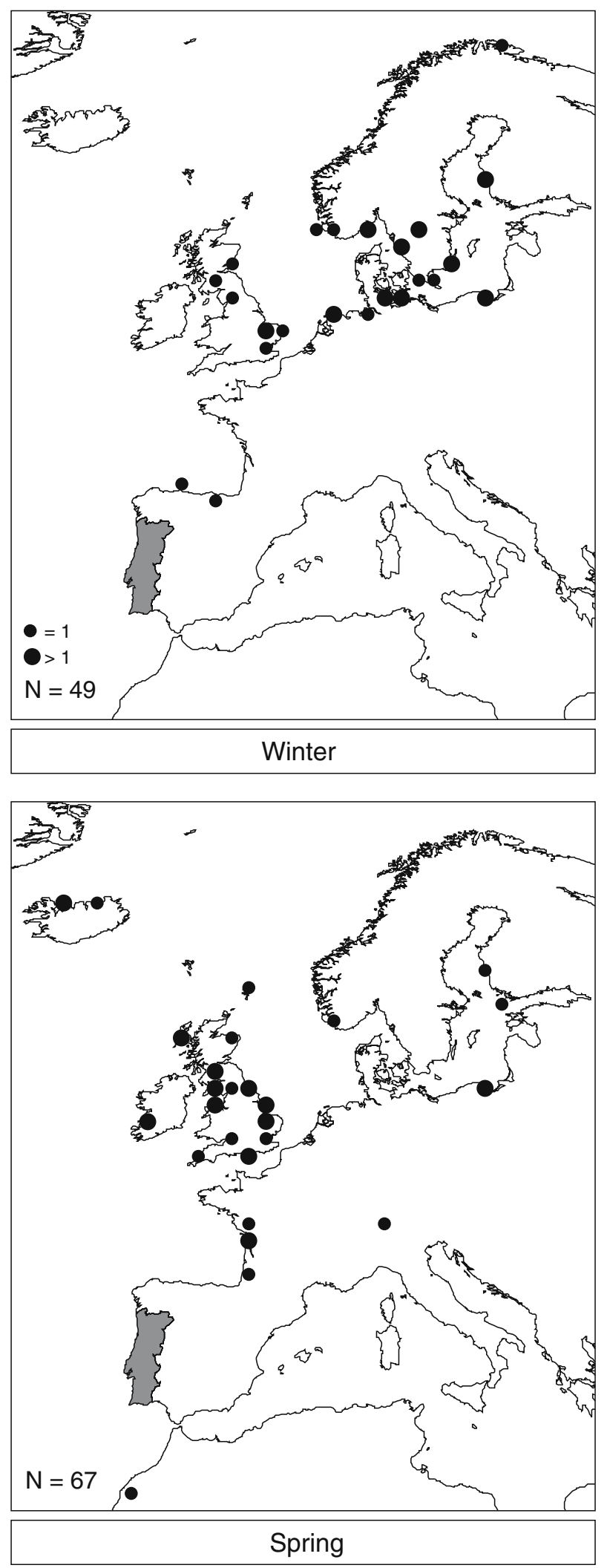

Fig. 3 Ringing locations of dunlin recovered in Portugal and recovery locations of dunlin ringed in Portugal during winter (December and January) and spring migration (April and May). Each dot represents all recoveries within a grid of $50 \mathrm{~km}$. Small dots indicate single samples and large dots more than one individual
Greenland were also recorded during this month, and these areas are also likely breeding areas for most of the British recoveries from August. In September, the situation was similar, with most records concentrated in Britain, many of them on the west coast. In contrast, the majority of records in October were linked to more eastern locations: the Baltic Sea area and the Wadden Sea, where the majority of the dunlin are thought to originate from the N Scandinavian and Russian tundra, and from the east coast of Britain. During mid winter (December and January), the pattern of recoveries was very similar to October. Most records showed links to Scandinavia, Baltic area, Wadden Sea and east coast of Britain. On spring migration (April and May), the recovery pattern was similar to that of early autumn migrants. Most birds were recorded in Britain and some were found on the west coast of France. Spring records also included recoveries of two chicks (pulli) from breeding areas in Iceland and the Shetland Islands, respectively, as well as three fledged juveniles recorded along the Baltic Sea coast.

Thus, autumn migrants show mainly north and northwesterly migration, whereas recoveries of the Portuguese winter populations reveal clear north-easterly migration routes. Spring migrants show a predominant northward migration with evidence of both north-westerly and north-easterly migrations. The recoveries also indicate that the dunlin that stay in Portugal in winter arrive late in the migration season, in October.

Three recoveries linked Portuguese birds to Moroccan winter grounds and migration stopover sites. No recoveries from other important wintering areas in Africa (e.g., Banc d'Arguin, Mauritania) were found. This may be an effect of limited sampling and occurrence of Portuguese migrants in these areas can by no means be excluded.

\section{Morphological characters}

There was a large overlap in morphology between sampling periods (Fig. 4). However, large birds were mainly present in the winter sample. Bill length was significantly different between seasons for both sexes (ANOVA: males, $F_{2,81}=18.73, \quad P<0.001$; females, $\left.F_{2,93}=10.36, P<0.001\right)$ and tarsus length differed significantly for males (ANOVA: males, $F_{2,81}=4.76$, $P<0.05$; females, $F_{2,93}=0.85, P=0.43$ ). Tukey post hoc tests showed that the winter sample was significantly different from both autumn and spring samples (males bill length: winter vs autumn $P<0.01$, winter vs spring $P<0.001$; females bill length: winter vs autumn $P<0.001$, winter vs spring migration $P<0.01$; male tarsus length: winter vs autumn $P<0.66$, winter vs spring $P<0.01$ ). No significant differences in morphology were found between spring and autumn samples (female bill length: autumn vs spring $P=0.95$; female tarsus length: autumn vs spring $P=0.60$; male bill 


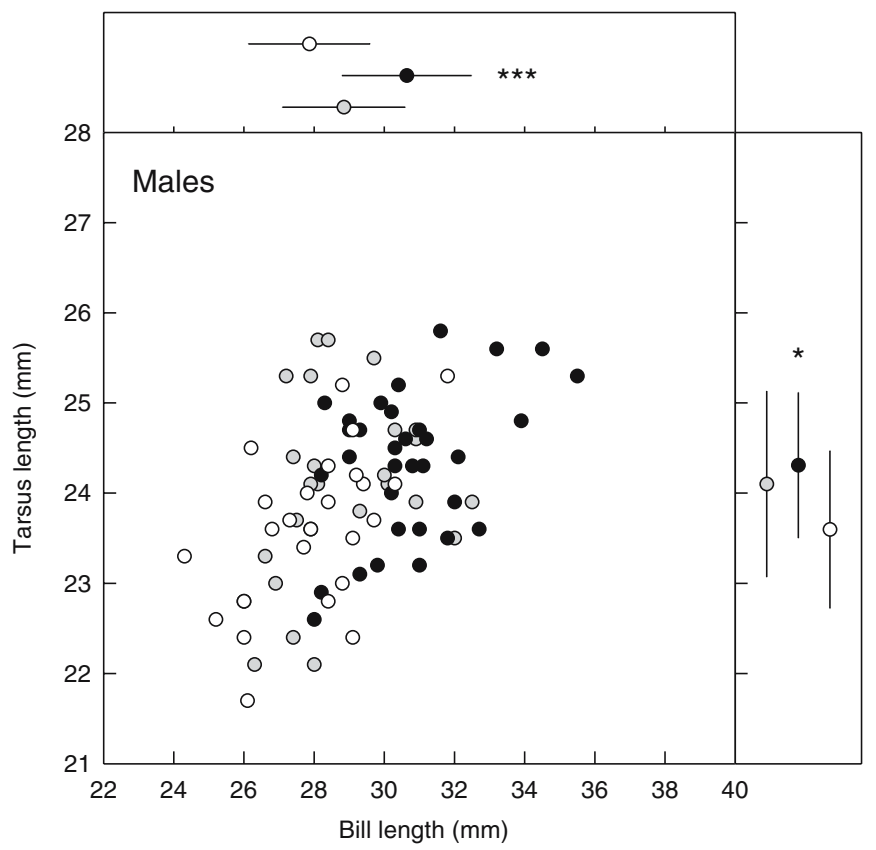

Fig. 4 Scatter plot of bill length and tarsus length of dunlin sampled in Portugal in autumn migration (August, September and October), winter (December and January) and spring migration (April and May). Mean and standard deviation for each season are

length: autumn vs spring $P=0.13$; male tarsus length: autumn vs spring $P=0.13$ ).

\section{Mitochondrial DNA}

An updated overview of mtDNA haplotypes in breeding populations (Fig. 1; Table 2) shows that all birds of the subspecies $C$. a. schinzii have the European haplotype, including samples from Iceland and the Baltic Sea region. In the nominate subspecies $C$. a. alpina, the European haplotype is predominant in breeding dunlin from northern Scandinavia and west Russia, whereas in

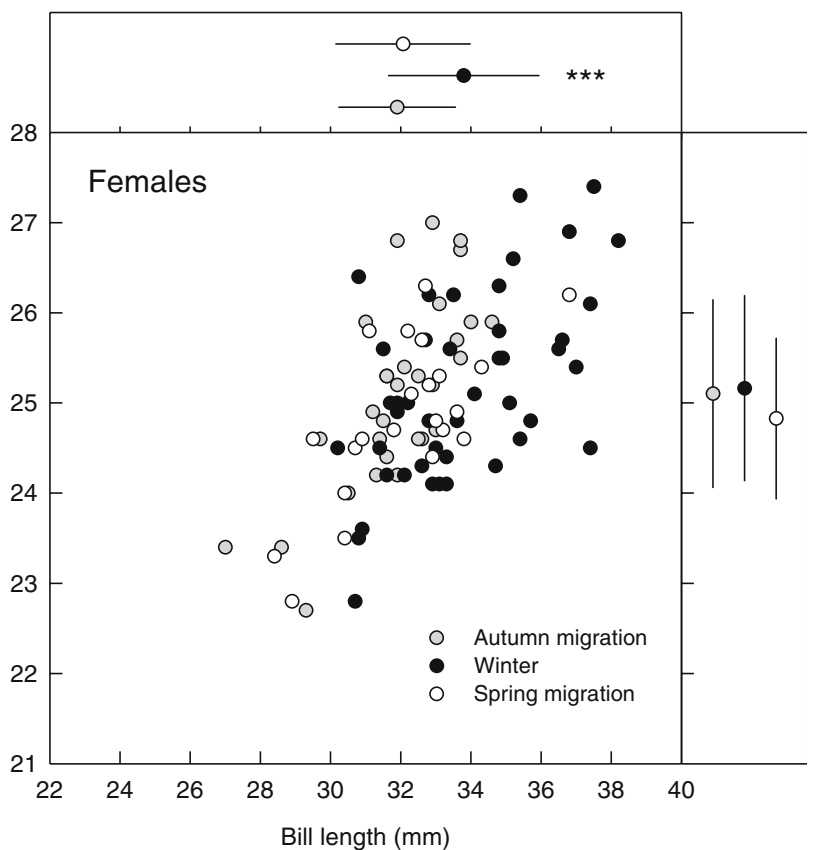

shown beside each graph. Significant differences between seasons shown by ANOVA are indicated by: $* P<0.05 ; * * P<0.01$; $* * * P<0.001$

central Siberia, the Siberian haplotype is predominant. In the western and central Palearctic, the frequency of Siberian haplotype increases with the longitude of the breeding site according to a sigmoidal logistic regression (Wennerberg 2001).

In Portugal, all dunlin sampled during the migration periods (autumn: 7 August to 2 October; spring: 2 to 22 May) had the European haplotype (Table 1), indicating a large influence of schinzii in these periods. The haplotype composition in winter (20 December-18 January) was clearly different from the migration periods, with a mixture of European $(79 \%)$ and Siberian haplotypes. The haplotype frequencies are significantly different

Table 2 Mitochondrial haplotypes of the breeding regions are shown in the first columns (see also Fig. 1). The last columns show Fisher exact tests comparing mitochondrial haplotypes of migrating and wintering dunlin in Portugal with the pooled haplotypes from the different breeding regions

\begin{tabular}{|c|c|c|c|c|c|c|}
\hline \multirow[t]{2}{*}{ Location } & \multirow[t]{2}{*}{ Eur } & \multirow[t]{2}{*}{$\mathrm{Sib}$} & \multirow[t]{2}{*}{$\%$ Eur } & \multicolumn{3}{|l|}{ Portugal } \\
\hline & & & & Autumn & Winter & Spring \\
\hline NE Greenland & 2 & 0 & 100 & - & 1.00 & - \\
\hline Iceland & 33 & 0 & 100 & - & $* *$ & - \\
\hline Baltic Sea & 99 & 0 & 100 & - & $* * *$ & - \\
\hline North Scandinavia & 36 & 5 & 88 & $*$ & 0.32 & $*$ \\
\hline North Russia & 51 & 13 & 80 & $* * *$ & 1.00 & $* * *$ \\
\hline Taimyr & 6 & 23 & 21 & $* * *$ & $* * *$ & $* * *$ \\
\hline Siberia east of Taimyr & 1 & 11 & 8 & $* * *$ & $* * *$ & $* * *$ \\
\hline
\end{tabular}

$n s$ not significant; "-_ represents not applicable

$* P<0.05$

$* * P<0.01$

$* * * P<0.001$ 
from spring and autumn (Fisher exact tests: spring $P<0.001$; autumn $P<0.001$ ), and shows clearly that the winter samples include birds of a more eastern breeding origin.

A more detailed analysis of age and sex composition was possible for the winter sample (Table 1). All juveniles had the European haplotype, while $25 \%$ of the adults had the Siberian haplotype. However, sample size for juveniles was low ( $n=12$ juveniles, 68 adults), and the haplotype frequencies of adults and juveniles were not significantly different (Fisher exact test: $P=0.06$ ). There were no difference in haplotype frequencies between males and females in winter (Fisher exact test: all individuals $P=0.41$; adults only $P=0.59$ ).

To estimate the origin of the Portuguese dunlin, we compared the haplotypes from the Portuguese samples to those of breeding populations. For the statistical analysis in Table 2, we assumed that no mixture of populations occurs in Portugal, and later we discuss how the results would be affected if this assumption is not fulfilled.

The mtDNA composition of the winter sample from Portugal differed significantly from the Icelandic and Baltic breeding populations (e.g., south Swedish and Estonian breeding populations), as well as from breeding populations in the Taimyr peninsula and further east in Siberia (Table 2), but it was similar to breeding populations in north Scandinavia and north Russia (Fig. 5; Table 2). Only two birds from Greenland have been analyzed for mtDNA, thus small sample size prevents us from rejecting this population as an origin for the winter population, but morphological measurements suggests that the Greenland populations are not involved. (To achieve a statistical power of $80 \%$, a sample from Greenland with $100 \%$ European haplotype would have had to include more than 31 birds in order to achieve a significant difference from the Portuguese winter sample.)
In contrast to the winter sample, the migrating birds from autumn and spring showed identical haplotype composition to the schinzii populations (e.g. in Iceland and south Sweden, possibly also to arctica from Greenland), but were significantly different from the north Scandinavian sample and all eastern breeding areas (Table 2).

\section{Discussion}

The results show differences in breeding origin between dunlin populations on Portuguese estuaries and reveal new links between breeding and wintering areas. The three types of evidence (ringing recoveries, morphometrics and mtDNA analysis) all support the same pattern and together they make it possible to discriminate the breeding ranges and migration routes for these populations.

Analysis of ringing recoveries discriminated two major migratory routes to Portugal, a westerly route via Britain and an easterly route through the Baltic Sea. The recoveries showed a clear longitudinal shift of records during autumn migration, revealing differences in migration routes taken by early (western) and late (eastern) autumn migrants. This pattern shifted in late autumn, between September and October. There was also a clear similarity of the pattern in migratory routes between October and winter, suggesting that it is the late migrants that settle to winter in Portugal.

Recoveries from Iceland and the Shetland Islands showed links between NW European breeding areas and Portugal, as expected, but no recoveries revealed direct links between Portugal and breeding areas further east, e.g. in northern Russia and western Siberia. Most of the records during late autumn migration and winter were from Scandinavia and the Baltic Sea area. Until now, it
Fig. 5 Frequencies of European mitochondrial DNA haplotype (with 95\% confidence interval) in dunlin from breeding populations and in samples of migrating and wintering dunlin in Portugal. Sample sizes and significance levels are shown in Table 2

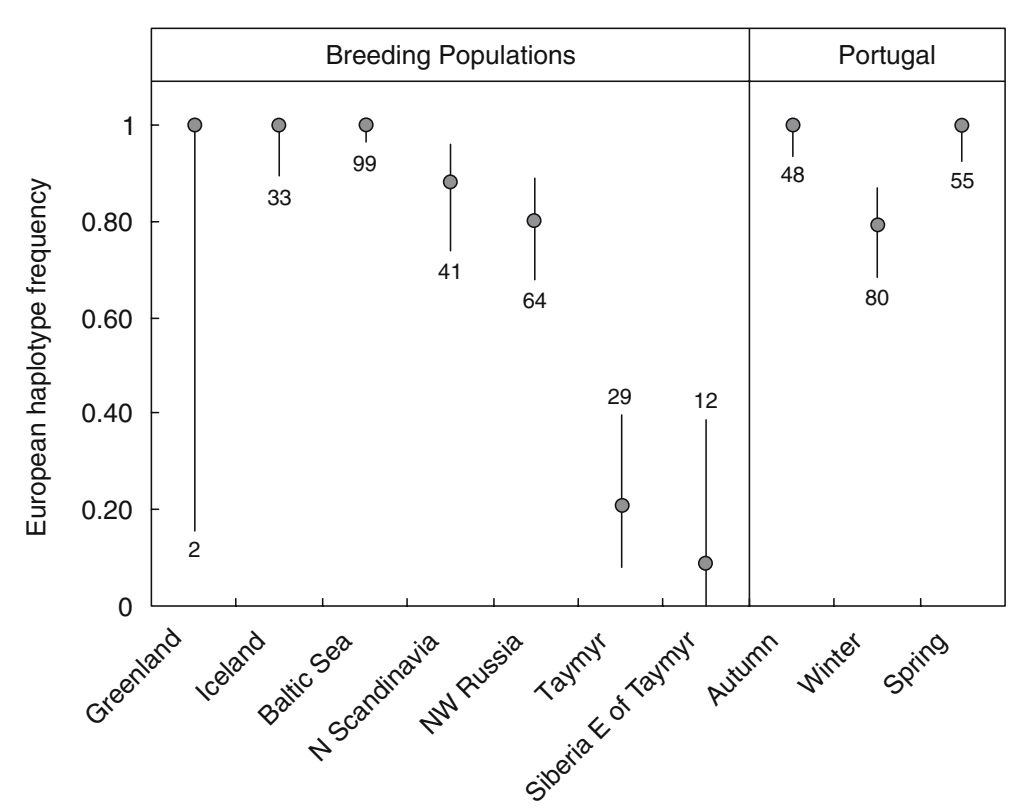


was unknown whether this was a consequence of low ringing effort on breeding areas in northern Russia and western Siberia, or the nonexistence of migratory links between these breeding areas and wintering grounds in Portugal. The only recoveries of breeding birds from northern Russia and western Siberia have so far been found in countries further north than Portugal: in Finland, Norway, Sweden, Denmark, Germany, Britain, Ireland and France (Hardy and Minton 1980; Greenwood 1984; Gromadzka 1989). However, the fact that most Portuguese winter records were registered at stopover sites such as Ottenby (Sweden) or Gulf of Gdansk (Poland), and the bulk of these Baltic migrants originate from the Russian arctic, clearly suggest links between Portugal and north Russian breeding areas. These winter records are unlikely to be recoveries of south Scandinavian and Baltic Sea area breeding birds, since these birds migrate at a different time period (Jönsson 1986), their total abundance is low compared to the total number of dunlin in Portugal, and they belong to a different subspecies.

Morphological data also show significant differences between migrating and wintering birds. The birds in the winter assemblages were larger, with longer bills and tarsi. These observations also support a more eastern origin, since the size of the birds (especially bill length) increases eastwards in this breeding region, and clearly differ between subspecies (Greenwood 1986; Engelmoer and Roselaar 1998). Comparisons with biometric data from breeding areas (Engelmoer and Roselaar 1998) show that the distribution of bill length in the winter sample is similar to those of C. a. alpina (North Fennoscandinavia: male, $30.6 \pm 1.7$; female, $34.3 \pm 1.7$; West Siberia (Kanin peninsula to Yamal): male, $32.4 \pm 0.9$; female, $34.6 \pm 2.2$ ) while the migrating populations in Portugal more closely resemble the other two subspecies, C. a. arctica (Northeast Greenland: male, 26.9 \pm 1.0 ; female, $30.1 \pm 1.3$ ) and schinzii (Iceland: male, $29.1 \pm 1.5$; female, $33.0 \pm 1.5$; Continental West Europe: male, $28.9 \pm 1.2$; female, $33.2 \pm 1.0$ ). The same pattern is observed when comparing tarsus lengths.

There is a large overlap in morphology between breeding populations (Engelmoer and Roselaar 1998). Earlier data from Batty (1993), using univariate analysis of bill length data from south of Portugal, indicated that the majority of dunlin caught in south Portugal during winter were $C$. a. schinzii and few $C$. a. alpina were considered to be included. During autumn migration, $6 \%$ of the birds were estimated to belong to the alpina subspecies. In contrast to our results, he found no significant differences between migrating and wintering birds. However, his dataset was based on unsexed birds, making it more difficult to separate the effects of sex and subspecies. In our present study, all birds were sexed genetically, which enhanced the reliability of the morphological comparisons and may explain some of the discrepancy between the datasets.

Our summary and expansion of data of mtDNA composition of breeding populations from Greenland to
Siberia show additional information on the variation in haplotype frequencies between populations. The comparison of Portuguese data with mtDNA of breeding populations allowed us to link winter populations with eastern breeding areas in Russia, while populations on spring and autumn migration were assigned to breeding populations further west (Greenland, Iceland or the Baltic region). The probability of rejecting single breeding populations is still low for some populations (e.g. Greenland), and further characterization of breeding populations with small sample sizes may enhance the discrimination of breeding birds from arctic regions where sampling effort has been low so far. The existence of dunlin with Siberian haplotypes in Portugal is a significant finding in that it ascertains the involvement of alpina populations as far southwest in the wintering range as Portugal. The haplotype frequencies also indicate that the majority of the dunlin wintering in Portugal originate from breeding areas in Russia.

During both autumn and spring migration, the complete lack of the Siberian haplotype indicates that no (or few) Siberian birds were present during the sampling periods. Rather, the haplotypes corresponded well to schinzii populations (and possibly arctica).

In contrast to the adult dunlin, all juveniles sampled during winter had the European haplotype. The limited number of sampled juveniles did not allow us to discern whether this was due to the existence of real age segregation in wintering grounds between juveniles and adults, or if it was an artefact of low sample size. If age segregation exists, the spatial scale may also be limited to areas within each estuary or between estuaries.

Our results gave no indication of sex segregation in dunlin, although the observed sex ratio in winter was uneven (male/female ratio $=0.74$ ). No sex differences in mtDNA haplotype frequencies were detected. However, segregation between male and female dunlin has been suggested for North American dunlin (Shepherd et al. 2001) and it cannot be excluded in the European system based only on data from Portugal, as segregation may occur elsewhere in the flyway.

In the statistical analysis, we have assumed that no mixing between breeding populations occurs on wintering grounds and during migration. No data is available for quantification of population mixture in Portugal during winter and migration, but it is likely that this occurs, as indicated by recovery data. If mixing occurs, this would not change the major conclusions drawn in this paper, but our winter data may imply presence of birds from even further east in Russia, from populations with a higher percentage of the Siberian haplotype (the closest population being those on Gydan Peninsula and western Taimyr Peninsula). It would also mean that a proportion of $C$. a. alpina may go undetected during migration. Thus, we cannot exclude the possibility of having a low proportion of alpina in these samples, or having some schinzii in winter. However, strong differences in composition between seasons are shown by 
mtDNA data as well as by morphological differences and ringing recoveries.

It would be interesting to obtain genetic data from the late migration period in October as our sampling for mtDNA analysis covered mainly the period of AugustSeptember in order to clarify the timing of arrival of the first wintering birds.

Our study demonstrated how a combination of three different methods can be efficiently used for revealing the migratory connectivity of dunlin populations along the East Atlantic flyway. Nevertheless, these different methodologies do not provide the same data resolution and applications. For instance, ringing recoveries have major logistical and analytical limitations, which are not compatible with the necessity to implement tools that can detect short-term variation on migration dynamics. In this scope, morphometrics combined with genetic sexing and population genetic markers are better candidates for improving the overall resolution of connectivity assignment.

Additional genetic markers will also be useful for discerning populations (Webster et al. 2002; Clegg et al. 2003). The use of amplified fragment polymorphisms, the integrated use of nuclear markers with higher mutation rates such as microsatellites, and the development of single nucleotide polymorphisms (SNPs) will provide the fine scale population resolution required for assignment of populations and will vastly improve our ability to track migratory movements at multiple scales (Morin et al. 2004). Moreover, the ongoing Chicken Genome Project (the first avian genome to be sequenced) provides the possibility of accurately identifying candidate genes to screen SNPs.

Other methods, such as stable isotope analysis (Hobson 1999; Chamberlain et al. 2000; Wennerberg et al. 2002) and satellite telemetry (Ueta et al. 2002; Fuller et al. 1998), can also be included in studies of migratory connectivity. However, several problems (e.g. weight of transmitters and more knowledge on geographic variation in isotope ratios) need to be addressed before their implementation.

While the approach used in this paper was tested in only one location on the East Atlantic flyway, ultimately the integration of similar data from several selected locations along this flyway will provide a more comprehensive understanding of the overall dunlin migration dynamics.

The results in this paper give evidence for migratory connectivity of dunlin populations between geographic areas previously not considered to be connected. They also show clear differences in breeding origin between birds that use Portuguese estuaries at different times of the year, and reveal differences in migration routes. These results are important when considering the future long-term conservation plans for the species, while similar methods may be used for other species. The results are relevant for conservation at different spatial scales, from conservation of local estuaries to flyway conservation.

\section{Zusammenfassung}

Zugkonnektivität und zeitliche Segregation beim Alpenstrandläufer (Calidris alpina) in Portugal-Hinweise über Morphologie, Beringungsdaten und mitochondrialer DNA

Zugkonnektivität spielt eine wichtige Rolle im Schutz von Langstreckenziehern. Hier untersuchen wir die Konnektivität ziehender Alpenstrandläufer (C. alpina) mit einem Schwerpunkt auf einem Rast- und Überwinterungsgebiet (Portugal), von dem bekannt ist, dass Zugrouten von Alpenstrandläufern aus einem weiten geographischen Bereich (drei Unterarten) zusammenlaufen, und dass die Populationen gleichzeitig oder zeitversetzt vorkommen. Wir kombinierten drei Methoden (Beringungsdaten, Morphometrie, Molekulargenetik), um Brutherkunft und Ausmaß zeitlicher Segregation von Alpenstrandläufern aufzudecken. Die Beringungsdaten zeigen eine zeitliche Separation von Alpenstrandläufern von unterschiedlichen Zugrouten. Vögel, die während August und September in Portugal festgestellt werden, mit Zugrouten über Großbritannien, zeigen Verbindungen $\mathrm{zu}$ Brutgebieten in Island und Grönland. Im Oktober tritt eine deutliche Verschiebung zu östlicheren Zugrouten auf, so dass die meisten portugiesischen Winterfunde aus Rastgebieten stammen, die an Zugrouten von Populationen aus Nordskandinavien und Russland liegen. Mitochondriale DNA (mtDNA) von portugiesischen Alpenstrandläufern wurde verglichen mit der von Vögeln aus Brutpopulationen. Frühlings- und Herbstgäste in Portugal gehören zu Populationen von $C$. a. schinzii und $C$. a. arctica, während die Winterpopulation sich deutlich dadurch unterscheidet, dass zusätzlich mtDNA Haplotypen von C. a. alpina auftreten. Wir fanden signifikante Unterschiede in der Morphologie (Schnabel- und Tarsuslänge), die die zeitliche Separation von Populationen/ Unterarten unterstützten, die sich in Beringungs- und mtDNA-Daten zeigten. Unsere Ergebnisse erbringen einen Nachweis für eine Zugkonnektivität von Populationen von Alpenstrandläufern zwischen Gebieten, die zuvor als nicht verbunden angesehen wurden. Sie bestätigen das Vorhandensein von deutlichen Unterschieden in der Herkunft von Vögeln in Portugal zu verschiedenen Zeiten im Jahr. Dies sind wichtige Daten für zukünftigen Langzeit-Schutzmaßnahmen.

Acknowledgements We would like to thank all that helped in capturing and processing the birds in the field. We also thank the Reserva Natural do Estuário do Tejo (RNET) for allowing us to capture birds in Tagus estuary, the Instituto da Conservação da Natureza (ICN) for the permission to catch birds and collect blood samples in Portugal (permit no. 110) and the Portuguese national ringing centre (ICN-CAN) for the ringing recoveries data. We would like to thank Jaime Ramos for valuable revisions to the manuscript. This research was funded by Fundação para a Ciência e a Tecnologia (FCT; grant PRAXIS XXI/BD/16250/98), N-O Berggrens fund (Lund University) and the National Centre for Biosystematics, Natural History Museum, University of Oslo. 


\section{References}

Batty L (1993) Computer analysis of wader morphometric data. Wader Study Group Bull 70:23-27

Chamberlain CP, Bensch S, Feng X, Åkesson S, Andersson T (2000) Stable isotopes examined across a migratory divide in Scandinavian willow warblers (Phylloscopus trochilus trochilus and Phylloscopus trochillus acredula) reflect their African winter quarters. Proc R Soc Lond B 267:43-48

Clegg SM, Kelly JF, Kimura M, Smith TB (2003) Combining genetic markers and stable isotopes to reveal population connectivity and migration patterns in a Neotropical migrant, Wilson's warbler (Wilsonia pusilla). Mol Ecol 12:819-830

Delany S, Reyes C, Hubert E, Pihl S, Rees E, Haanstra L, van Strien A (1999) Results from the International Waterbird Census in the Western Palearctic and Southwest Asia, 1995 and 1996. Wetlands International Publication 54, Wageningen

Engelmoer M, Roselaar CS (1998) Geographical variation in Waders. Kluwer Academic, Dordrecht

Ferreira AC (1980) Recapturas em Portugal de aves anilhadas no estrangeiro (1972-1974). Cyanopica 2:57-94

Freire O (1969) Aves anilhadas no estrangeiro e capturadas em Portugal (1966-1967). Cyanopica 1(4):51-73

Fuller MR, Seeger WS, Schueck LS (1998) Routes and travel rates of migrating Peregrine Falcons Falco peregrinus and Swainson's Hawks Buteo swainsoni in the Western Hemisphere. J Avian Biol 29:433-440

Galbraith H, Jones R, Park R, Clough J, Herrod-Julius S, Harrington B, Page G (2002) Global climate change and sea level rise: potential losses of intertidal habitat for shorebirds. Waterbirds 25:173-183

Greenwood JG (1984) Migration of Dunlin Calidris alpina: a world-wide overview. Ring Migr 5:35-39

Greenwood JG (1986) Geographical variation and taxonomy of the Dunlin Calidris alpina (L.). Bull Brit Ornithol Club 106:43-56

Griffiths R, Double MC, Orr K, Dawson RJG (1998) A DNA test to sex most birds. Mol Ecol 7:1071-1075

Gromadzka J (1989) Breeding and wintering areas of Dunlin migrating through southern Baltic. Orn Scand 20:132-144

Gromadzka J, Ryabitsev VK (1998) Siberian Dunlin Calidris alpina migrate to Europe: first evidence from ringing. In: Hötker $\mathrm{H}$, Lebedeva E, Tomkovich PS, Gromadzka J, Davidson NC, Stroud DA, West RB (eds) Migration and international conservation of waders. Research and conservation on north Asian, African and European flyways. International Wader Studies 10, pp 88-90

Hardy AR, Minton CDT (1980) Dunlin migration in Britain and Ireland. Bird Study 27:81-92

Hobson KA (1999) Tracing origins and migration of wildlife using stable isotopes: a review. Oecologia 120:314-326

del Hoyo J, Elliott A, Sagatal J (1996) Handbook of the birds of the world, vol. 3. Hoatzins to Auks. Lynx Edicions, Barcelona

Jönsson PE (1986) The migration and wintering of Baltic Dunlin Calidris alpina schinzii. Vår Fågelv 11(Suppl.):71-78

Kimura L, Clegg SM, Lovette IJ, Holder KR, Girman DJ, Milá B, Wade P, Smith TB (2002) Phylogeographical approaches to assessing demographic connectivity between breeding and overwintering regions in a Nearctic-Neotropical warbler (Wilsonia pusilla). Mol Ecol 11:1605-1616

Lindström Å, Agrell J (1999) Global change and possible effects on the migration and reproduction of arctic-breeding waders. Ecol Bull 47:145-159

Morin PA, Luikart G, Wayne RK, SNP workshop group (2004) SNPs in ecology, evolution and conservation. Trends Ecol Evol 19:208-216
Pienkowski MW, Dick WJA (1975) The migration and wintering of Dunlin Calidris alpina in north-west Africa. Ornis Scand 6:151167

Pienkowski MW, Evans PR (1984) Migratory behavior of shorebirds in the western Palearctic. In: Burger J, Olla BL (eds) Behavior of marine animals, vol. 6. Shorebirds Migration and foraging behavior. Plenum, New York, pp 73-123

Prater T, Marchant J, Vuorinen J (1977) Guide to the identification and ageing of holarctic waders. British Trust for Ornithology, Tring, UK

Sambrook J, Fritsch EF, Maniatis T (1989) Molecular cloning-a laboratory manual, 2nd edn. Cold Spring Harbor Laboratory Press, New York

Shepherd PCF, Lank DB, Smith BD, Warnock N, Kaiser GW, Williams TD (2001) Sex ratios of Dunlin wintering at two latitudes on the Pacific coast. Condor 103:352-360

Smit CJ, Piersma T (1989) Numbers, midwinter distribution and migration of wader populations using the East Atlantic flyway. In: Boyd H, Pirot JY (eds) Flyways and reserve networks for water birds. IWRB Sec. Publ. 9, Slimbridge, pp 24-63

Smith HG, Wennerberg L, von Schantz T (1996) Adoption or infanticide: options of replacement males in the European starling. Behav Ecol Sociobiol 38:91-197

Snow DW, Perrins CM (eds) (1998) The birds of Western Palearctic. Concise edition, vol. 1. Non-passerines. Oxford University Press, Oxford

Svensson L (1992) Identification guide to European passerines, 4th edn. Lars Svensson, Södertälje, Stockholm, Sweden

Ueta M, Antonov A, Artukhin Y, Parilov M (2002) Migration routes of Eastern Curlews tracked from far east Russia. Emu 102:345-348

Webster MS, Marra PP, Haig SM, Bensch S, Holmes RT (2002) Links between worlds: unraveling migratory connectivity. Trends Ecol Evol 17(2):76-83

Wenink PW, Baker AJ (1996) Mitochondrial DNA lineages in composite flocks of migratory and wintering dunlin (Calidris alpina). Auk 113:744-756

Wenink PW, Baker AJ, Tilanus MGF (1993) Hypervariable control region sequences reveal global population structuring in a long-distance migrating shorebird, the dunlin (Calidris alpina). Proc Natl Acad Sci USA 90:94-98

Wennerberg L (2001) Breeding origin and migration pattern of dunlin (Calidris alpina) revealed by mitochondrial DNA analysis. Mol Ecol 10:1111-1120

Wennerberg L, Holmgren N, Jönsson PE, von Schantz T (1999) Genetic and morphological variation in breeding dunlin Calidris alpina in the Palearctic tundra. Ibis 141:391-398

Wennerberg L, Pettersson J, Holmgren NMA (2001) The timing of autumn migration and moult in two mtDNA haplotypes of Dunlin Calidris alpina at a stop-over site in the Baltic Sea. In: Wennerberg L (ed) Genetic variation and migration of waders. PhD Thesis, Lund University, Sweden, pp. 117-127

Wennerberg L, Klaassen M, Lindström A (2002) Geographical variation and population structure in the White-rumped Sandpiper Calidris fuscicollis as shown by morphology, mitochondrial DNA and carbon isotope ratios. Oecologia 131:380-390

Wetlands International (2002) Waterbird population estimates, 3rd edn. Wetlands International Global Series 12, Wageningen, The Netherlands

Wymenga E, Engelmoer M, Smit CJ, van Spanje TM (1990) Geographical breeding origin and migration of waders wintering in West Africa. Ardea 78:83-112

Zar JH (1999) Biostatistical analysis, 4th edn. Prentice-Hall, New Jersey 